\title{
Receptor guanylyl cyclases in mammalian olfaction: from genes to function
}

\section{Frank Zufall}

Address: Department of Physiology, University of Saarland, School of Medicine, 66421 Homburg, Germany

Email: Frank Zufall - frank.zufall@uks.eu

from 4th International Conference of cGMP Generators, Effectors and Therapeutic Implications

Regensburg, Germany. 19-2I June 2009

Published: II August 2009

BMC Pharmacology 2009, 9(Suppl I):S45 doi:I0.1186/147I-22 I0-9-SI-S45

This abstract is available from: http://www.biomedcentral.com/I47I-22I0/9/SI/S45

(c) 2009 Zufall; licensee BioMed Central Ltd.

The contributions of guanylyl cyclases to sensory signaling in the olfactory system have been unclear. Recently, studies of a specialized subpopulation of olfactory sensory neurons (OSNs) located in the main olfactory epithelium have provided important insights into the neuronal function of one receptor guanylyl cyclase, GC-D. Genetargeted mice expressing reporters such as $\beta$-galactosidase and green fluorescent protein in OSNs that normally express GC-D have allowed investigators to identify these neurons in situ, facilitating anatomical and physiological studies of this sparse neuronal population. The specific perturbation of GC-D function in vivo has helped to resolve the role of this guanylyl cyclase in the transduction of olfactory stimuli. Similar approaches could be useful for the study of the orphan receptor GC-G, which is expressed in another distinct subpopulation of sensory neurons located in the Grueneberg ganglion. This lecture will discuss the key findings that have reinvigorated the study of guanylyl cyclase function in the olfactory system.

\section{References}

I. Leinders-Zufall T, Cockerham RE, Michalakis S, Biel M, Garbers DL, Reed RR, Zufall F, Munger SD: Contribution of the receptor guanylyl cyclase GC-D to chemosensory function in the olfactory epithelium. Proc Natl Acad Sci USA 2007, 104: I4507-I45 I2.

2. Munger SD, Leinders-Zufall T, Zufall F: Subsystem organization of the mammalian sense of smell. Annu Rev Neurosci 2009, 71:115-140.

3. Zufall F, Munger SD: Receptor guanylyl cyclases in mammalian olfactory function. Mol Cell Biochem in press. 